\title{
Production of Endemic Microcrustacean Phronima Suppa (Phronima sp) to Subtitute Artemia salina in Tiger Prawn Cultivation
}

\author{
Muhammad Hattah Fattah ${ }^{1 *}$, Muh. Saenong ${ }^{2}$, Asbar ${ }^{1}$ and St Rahbiah Busaeri ${ }^{3}$
}

${ }^{1}$ Program Studies of Coastal and Ocean Engineering Management Graduate Program, Indonesian Muslim University, Indonesia

${ }^{2}$ Department of Fisheries and Aquaculture Marine Science, Indonesian Muslim University, Indonesia

${ }^{3}$ Faculty of Agriculture, Department of Agribusiness Indonesian Muslim University, Indonesia

\begin{abstract}
Phronima suppa (Phronima sp.) belongs to an endemic microcrustacea species inhabiting certain brackish water pond in Wiringtasi Village, Suppa Sub-district, Pinrang Regency, Indonesia. It has an important role to increase vitality and immunity of tiger prawn (Penaeus monodon) and to improve environmental quality of the brackish water pond. This species has potential chance to substitute the use of Artemia. Population of Phronima suppa in nature fluctuates, falls and even perishes after around 15 days. This study aims to produce Phronima suppa to be used as inoculant in the prawn brackish water pond and to substitute the use of Artemia in hatchery. The study is conducted in May to November, 2013 in the Field Laboratory of Fisheries and Maritime Science, Muslim University of Indonesia in Pinrang Regency. Phronima suppa is cultivated in controlled basin under treatment (A) by Chlorella sp, treatment (B) by Chaetoceros sp, and treatment (C) by combining Chlorella sp and Chaetoceros sp. Observed variables consist of production and water quality. The study is designed in form of Completely Randomized Design (CRD) by three treatments, while each of the treatments consist of three repetitions. Combination of Chlorella $\mathrm{sp}$ and Chaetoceros sp (treatment $\mathrm{C}$ ) delivers the highest production by $35.67 \pm 15.01$ individual/l followed by treatment $\mathrm{B}$ by $34.67 \pm 7.51$ individual/l and treatment $A$ by $27.35 \pm 0.57$ individual. This production increases in day 17 up to day 24. Productive period of Phronima suppa in the controlled basin is longer than in endemic habitat.
\end{abstract}

Keywords: Tiger prawn; Production; Artemia; Phronima; Plankton

\section{Introduction}

For the last twenty years, tiger prawn aquaculture industry has been attacked by white spot syndrome (WSSV) and Vibrio harveyi affected by the decrease of environmental capacity [1-11], lousy management of aquaculturalist [12-16] and the impacts of extreme climate change in consequence of global warming. The viruses affect about $70 \%$ of brackish water pond area in Indonesia at marginal and idle state as attacked by WSSV and V. Harveyi virus. Unproductive brackish water pond area in South Sulawesi, Indonesia covers an area of about 39,022 ha. It is predicted that crop failure in South Sulawesi wreaks loss of aquaculturalist around USD33.4 million per year. Loss prediction affected by shrimp disease outbreak in Indonesia reaches more than USD300 million or more than IDR3 trillion per year [13].

South Sulawesi has been appointed to be development center for tiger prawn (Penaeus monodon Fabricius) in Indonesia. Appointed development center for tiger prawn in South Sulawesi is located in Pinrang Regency [17]. For the last three years, population of Phronima $s p$ grows up naturally in certain people's brackish water area in Suppa Sub-district, Pinrang Regency [18]. Phronima suppa belongs to micro crustacean from genus Phronima and it is endemically live in the waters of people's brackish water in Wiringtasi Village and Tasiwale Village, Suppa Sub-district. Phronima suppa could not be found in brackish water and waters out of those villages. The existence of Phronima suppa becomes an initial indicator for aquaculturalist in Suppa Sub-district as presumption of tiger prawn cultivation success to the under-attacked brackish water area by WSSV and V. harveyi virus [18].

Observation of the last two years shows that in average, population of Phronima suppa in brackish water area may generate tiger prawn survival rate of more than 70 percent for four months during period of cultivation. In the other area where Phronima suppa were not found, survival rate of cultivated tiger prawn as just about 10 percent [18]. It is assumed that Phronima suppa has an important role to improve water quality and brackish water's basic substrate in compliance with the conditions of tiger prawn. Besides, it also becomes natural feed for the cultivated tiger prawn. The better water and soil quality restrains explosive growth of upsetting pathogen, especially for WSSV and V. harveyi virus. Furthermore, rich nutrient in Phronima suppa, as what has been presumed, may support the growth and natural immunity formation on tiger prawn against upsetting pathogen. One last year, the use of Phronima suppa in marginal brackish water ponds of Wiringtasi Village and Tasiwalie Village have produced tiger shrimp by $150-300$ $\mathrm{kg} / \mathrm{ha}$ around two-months of rearing period.

Phronima suppa has a potency of being alternative natural feed by replacing Artemia which is commonly given to fish and tiger prawn hatchery. Artemia salina cyst belongs to a high-priced import product which continually more expensive up to 180.70 percent since last year, so it affects competitiveness of fisheries and tiger prawn product in Indonesia. Phronima suppa could be an alternative or substitutive feed replacing Artemia, so it may raise production efficiency and product competitiveness of prawn in Indonesia.

Informational restrictiveness on biological, ecological and physiological characteristics and cultivation techniques become main constraints in Phronima suppa's cultivation development and

*Corresponding author: Muhammad Hatta Fattah, Indonesian Muslim University Urip Sumoharjo, Makassar (90 231), Indonesia, Tel: 62-411-455666; E-mail: h.fattah2014@yahoo.com

Received July 05, 2014; Accepted August 05, 2014; Published August 12, 2014

Citation: Fattah MH, Saenong M, Asbar, Busaeri SR (2014) Production of Endemic Microcrustacean Phronima Suppa (Phronima $s p$ ) to Subtitute Artemia salina in Tiger Prawn Cultivation. J Aquac Res Development 5: 257. doi:10.4172/21559546.1000257

Copyright: (c) 2014 Fattah MH, et al. This is an open-access article distributed under the terms of the Creative Commons Attribution License, which permits unrestricted use, distribution, and reproduction in any medium, provided the original author and source are credited. 
production artificially and massively. Previous study to produce Phronima suppa artificially had been conducted by [18]. However, in the first week of the study, its mortality rate reaches 100 percent. Unclear details on quality conditions of media and substrate, fertilizer and feed needs as well as cultivation management become the main factors of Phronima suppa's low production in artificial manner.

The dynamics of habitat and endemic environment is determined by hydro-oceanography diversity, soil and substrate as well as brackish water management. Biological potency diversity is determined by abundance, homogeneity and domination of Phronima suppa. Reproduction potency of Phronima suppa is determined by availability of mature broodstock and fecundity rate. Determinant of endemic habitat and environmental dynamics as well as biological potency of Phronima suppa is dominant attributes in production technology development of developed Phronima suppa artificially. Production in the controlled basin becomes an important factor in supplying continual Phronima suppa to support tiger prawn hatchery and cultivation management $[9,19]$. The study aims to produce Phronima suppa continually to be used as inoculant in prawn brackish water pond and to substitute the use of Artemia in hatchery.

\section{Materials and Methods}

The study is conducted in May to November, 2013 in the Field Laboratory of Fisheries and Maritime Science, Muslim University of Indonesia in Pinrang Regency. Phronima suppa is cultivated in the controlled basin under treatment of Chlorella sp (A), Chaetoceros sp (B), and combination of Chlorella sp and Chaetoceros sp (C). Cultivation on these plankton species applies the system based on the study of [20-26]. Phronima suppa is dispersed onto each of these basins

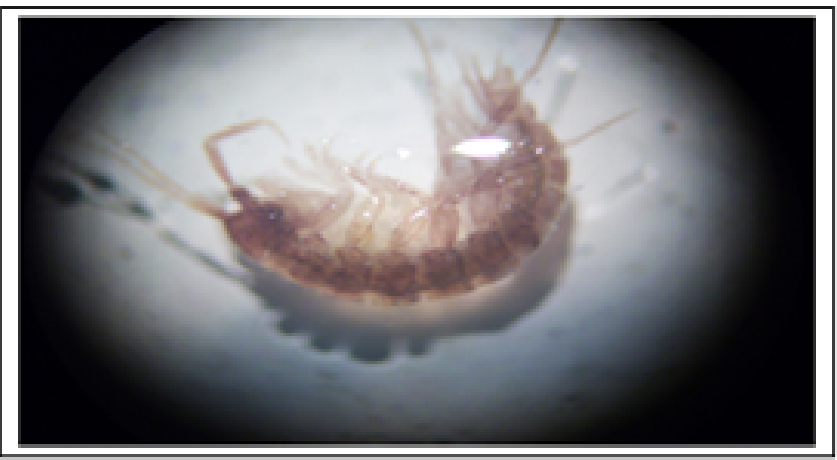

Figure 1: Phronima suppa (Phronima sp) [27].

\begin{tabular}{|c|c|c|c|c|}
\hline \multirow{2}{*}{$\begin{array}{c}\text { Observation } \\
\text { Period }\end{array}$} & Repetition & \multicolumn{3}{|c|}{ Treatment } \\
\cline { 2 - 5 } & 1 & A & B & C \\
\hline \multirow{4}{*}{ Day 17 } & 2 & 24.72 & 16.67 & 11.11 \\
\cline { 2 - 5 } & 3 & 16.67 & 16.67 & 25.00 \\
\cline { 2 - 5 } & Amount & 59.17 & 55.56 & 25.00 \\
\cline { 2 - 5 } & Average & $19.72 \pm 4.36$ & $18.52 \pm 3.20$ & $20.37 \pm 8.02$ \\
\hline \multirow{4}{*}{ Day 24 } & 1 & 27.00 & 35.00 & 35.00 \\
\cline { 2 - 5 } & 2 & 28.06 & 42.00 & 51.00 \\
\cline { 2 - 5 } & 3 & 27.00 & 27.00 & 21.00 \\
\cline { 2 - 5 } & Amount & 82.06 & 104.00 & 107.00 \\
\cline { 2 - 5 } & Average & $27.35 \pm 0.57$ & $34.67 \pm 7.51$ & $35.67 \pm 15.01$ \\
\hline
\end{tabular}

Table 1: Production of Phronima suppa (individual/l) during research. by 100 individuals per basin (Figure 1). Volume of each basin is 301 or dispersion density of each basin is 3.33 or 3.00 individual/l $[27,28]$.

Observed variables consist of production and water quality. Production of Phronima suppa is determined by equation as follows:

$\mathrm{P}=\mathrm{Nt} / \mathrm{V}$

$\mathrm{P}=$ Production (individual $/ \mathrm{l}$ )

$\mathrm{Nt}=$ Amount of Phronima suppa in the end of study (individual)

$\mathrm{V}=$ Water volume $(\mathrm{l})$

Observed water quality consists of temperature, salinity, dissolved oxygen, $\mathrm{pH}$, and ammonia as applied by previous researchers [10,2941]. The study is designed in form of Completely Randomized Design (CRD) by three treatments, while each of the treatments consist of three repetitions $[19,42]$.

\section{Findings and Discussion}

Found plankton in endemic habitat of Phronima suppa is 25 genera consisting of 14 genera from species phytoplankton and 11 genera from species zooplankton [27]. Given plankton becomes prior feed in the controlled basin as in the study of [26,43]. Production of Phronima suppa in every basin is presented in following Table 1.

Production of Phronima suppa in every treatment increases over observation period. Initial dispersion in every treatment and repetition by 3.33 or equals to 3.00 individual/l increases over observation period. The highest production is gained in day 17 by amount of every treatment as follows: treatment $\mathrm{C}(20.37 \pm 8.02$ individual/l), treatment A $(19.72 \pm 4.36$ individual/l) and treatment B (18.52 \pm 3.20 individual/l). In day 24 , highest production is gained by treatment C (35.67 \pm 15.01 individual/l) followed by treatment B (34.67 \pm 7.51 individual/l) and treatment A (27.35 \pm 0.57 individual/l). In day 24 , the order of production changes where the highest production is reached by the second and third treatment compared to observation in day 17 .

Result of variance analysis toward all of plankton-added treatments have unreal effect statistically concerning the production of Phronima suppa $(\mathrm{P}>0.05)$ in day 17 or day 24 due to the production of Phronima suppa in all treatments are considered as high. It can be proved by comparing the findings above and the findings of [28]) as presented in Table 2 and Figure 2. The highest product average based on the findings of [28] by feeding brackish water bottom soil substrate (treatment $Q$ ) in day 24 is $22.53 \pm 8.08$ individual/l; then followed by feeding silk algae substrate (Chaetomorpha sp) or treatment $\mathrm{P}$ is $7.72 \pm 7.42$ individual/l and feed combination of brackish water bottom soil substrate and silk algae or treatment $\mathrm{R}$ is $4.90 \pm 1.96$ individual/l. The death of silk algae in the observed basin causes the death of Phronima suppa. Then, decomposition of silk algae in the observed basin makes the observed object stress and dead $[15,23]$. Findings on the use of substrate takes an obvious effect $(\mathrm{P}<0.05)$ on the highest production by giving brackish water bottom soil substrate (treatment $\mathrm{Q}$ ) at the same findings of [4447].

In fact, treatment $\mathrm{C}$ produce a higher product average compared to treatment $\mathrm{B}$ and $\mathrm{A}$ in day 24 (Table 1 and Figure 2). Based on the findings of $[20,25]$. It is explained that Chaetoceros sp contains $35.00 \%$ protein, $6.90 \%$ fat, $6.60 \%$ carbohydrate and $28.00 \%$ ash content. Chlorella sp contains $21.85 \%$ protein, $2.41 \%$ fat and $23.78 \%$ carbohydrate. Treatment $\mathrm{C}$ made from the combination of Chaetoceros sp and Chlorella sp supplies the more complete and varied nutrient to produce the highest production compared to treatment $\mathrm{A}$ and $\mathrm{C}$ in day 24. 
Citation: Fattah MH, Saenong M, Asbar, Busaeri SR (2014) Production of Endemic Microcrustacean Phronima Suppa (Phronima sp) to Subtitute Artemia salina in Tiger Prawn Cultivation. J Aquac Res Development 5: 257. doi:10.4172/2155-9546.1000257

Page 3 of 5

\begin{tabular}{|c|c|c|}
\hline Treatment & Repetition & Production (individual/I) \\
\hline \multirow{4}{*}{$\mathrm{P}$} & 1 & 15.58 \\
\cline { 2 - 3 } & 2 & 6.74 \\
\cline { 2 - 3 } & 3 & 0.84 \\
\cline { 2 - 3 } & Total & 23.16 \\
\cline { 2 - 3 } & Average & $7.72 \pm 7.42$ \\
\cline { 2 - 3 } & 1 & 29.22 \\
\hline \multirow{4}{*}{$\mathrm{Q}$} & 2 & 24.81 \\
\cline { 2 - 3 } & 3 & 13.55 \\
\hline \multirow{4}{*}{$\mathrm{R}$} & Total & 67.58 \\
\hline & Average & $22.53 \pm 8.08$ \\
\hline & 1 & 4.42 \\
\hline & 2 & 3.22 \\
\hline & 3 & 7.06 \\
\hline & Total & 14.70 \\
\hline & Average & $4.90 \pm 1.96$ \\
\hline
\end{tabular}

Table 2: Product average of Phronima suppa based on the findings of Fattah et al., [28] in day 24 .

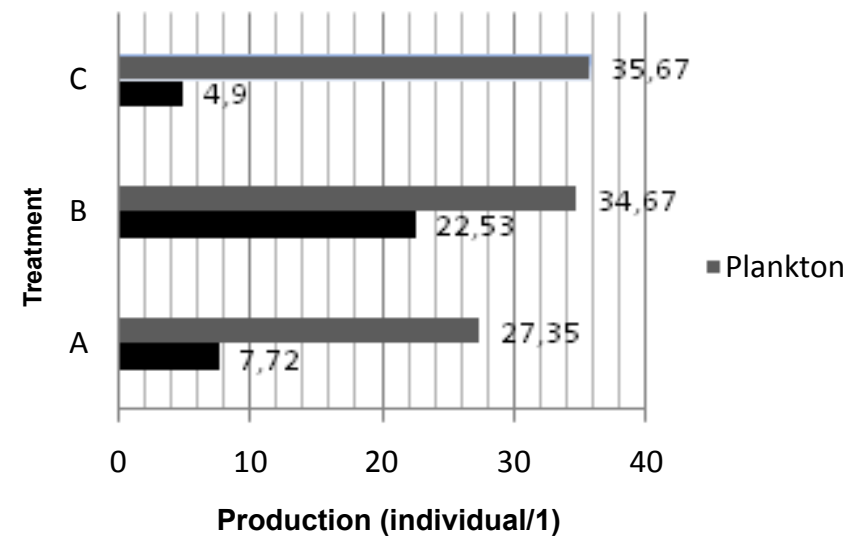

Figure 2: Average production of Phronima suppa compared to the findings of Fattah et al., [28] in day 24.

In day 17 , the highest average production is reached by treatment C $(20.37 \pm 8.02$ individual/l) followed by treatment A $(19.72 \pm 4.36$ individual/l) and treatment $\mathrm{B}(18.52 \pm 3.20$ individual/l). The highest average production in day 24 is gained by treatment $\mathrm{C}(35.67 \pm 15.01$ individual/l) followed by treatment B (34.67 \pm 7.51 individual/l) and treatment $\mathrm{A}(27.35 \pm 0.57$ individual/l). Production in day 1 , day 17 and day 24 are presented in Figure 3.

Production of Phronima suppa increases gradually from day 17 to day 24 (Figure 3). Production enhancement depicts that production of Phronima suppa is in logarithmic phase and it has not reached stationary phase (Figure 3). Production of Phronima suppa in this study has not reached subsequent phase, i.e. stationary phase (c), depletion phase (d) or death phase (e). Growth curve of Phronima suppa follows common growth model of water organism [16,39,41,48-50]

Productive period of Phronima suppa in controlled basin is longer than in endemic habitat. Stationary phase (c), depletion phase (d) and death phase (e) in endemic habitat occur in day 15 [27]. These three phases have not been determined in this study (Figure 4).

Continual availability of natural feed and complete environmental factor control affects productive period of Phronima suppa which is longer than its productive period in controlled basin compared to endemic habitat. It becomes an indication that Phronima suppa may be produced on a sustained basis by feeding combination of phytoplankton species Chlorella sp and Chaetoceros sp. It opens up an opportunity to produce Phronima suppa as a substitution of Artemia salina for the operating-hatchery needs and brackish water cultivation.

Life of Phronima suppa is highly affected by media quality. It conforms to the statement of $[1,48]$ that the life of waters organism is highly affected by physical and chemical factor of the waters. As a whole, media quality in all treatments are homogeneous, so they can meet the requirements of CRD design, but they are negatively affecting research process. All parameters are in appropriate range with value of media quality condition based on the reference (Table 3). Taken together, media inside of controlled basin meets the life requirements of Phronima suppa. It correlates to the findings of [27] who observes population of Phronima suppa in its endemic habitat.

Ammonia content in the observed basin is higher than what is written in the reference. Ammonia concentration in the observed basin comes from metabolism of testing animal and plankton. It depicts that Phronima suppa has high tolerance toward ammonia content. The effect of high ammonia content in the observed basin may be neutralized or controlled by plankton.

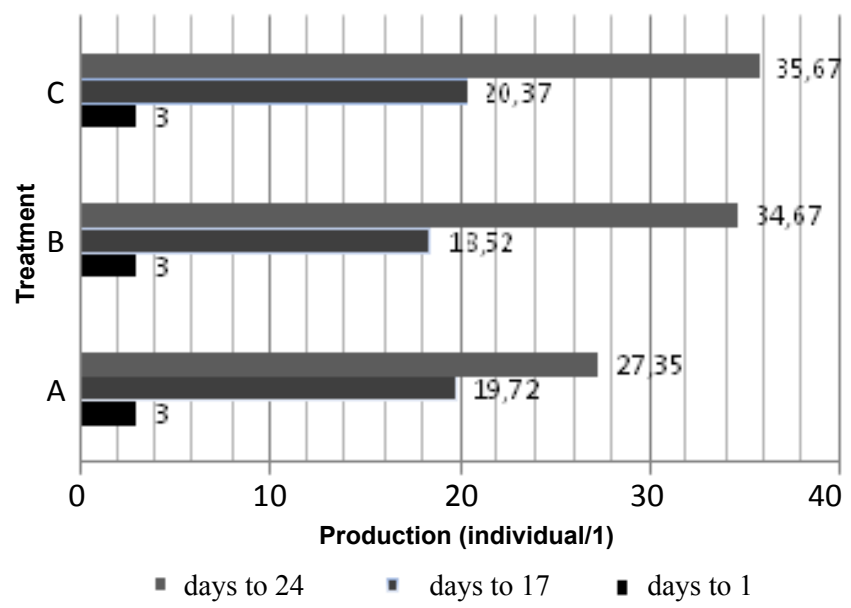

Figure 3: Average production of Phronima suppa during research.

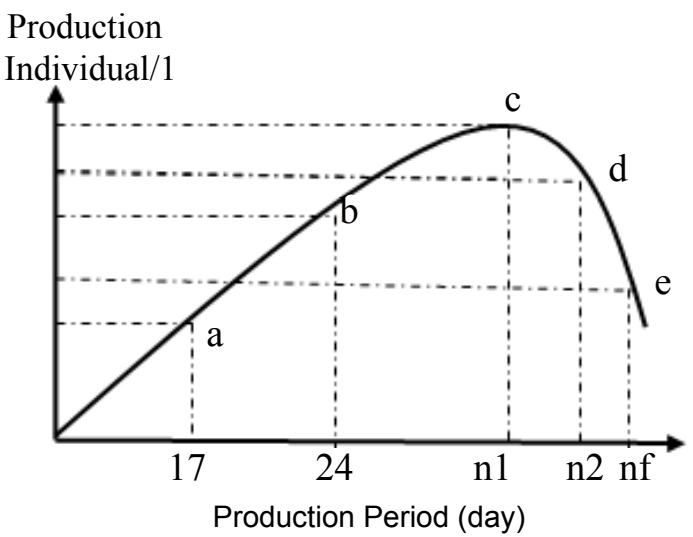

Figure 4: Production curve of Phronima suppa (a=production phase $b=$ logarithmic phase; $c=$ stationary phase; $d=$ depletion phase; $e=$ death phase, $n=$... productive period in certain phase). 
Citation: Fattah MH, Saenong M, Asbar, Busaeri SR (2014) Production of Endemic Microcrustacean Phronima Suppa (Phronima sp) to Subtitute Artemia salina in Tiger Prawn Cultivation. J Aquac Res Development 5: 257. doi:10.4172/2155-9546.1000257

Page 4 of 5

\begin{tabular}{|c|c|c|c|c|}
\hline \multirow{2}{*}{ Observed media factors } & \multicolumn{3}{|c|}{ Indicator value range of media quality } & Indicator value range of media quality based on the \\
reference $[27]$
\end{tabular}

Table 3: Indicator value range of media quality based on the calculation and indicator value range of media quality which meets the life and growth requirement of Phronima suppa.

\section{Conclusion and Suggestion}

Based on the findings, it is concluded that Phronima suppa may be produced in controlled basin by feeding plankton from species Chaetoceros sp, Chlorella sp, and combination of Chaetoceros sp and Chlorella sp. Feed combination of Chaetoceros sp and Chlorella sp delivers a higher product compared to single feed made from Chaetoceros sp or Chlorella sp. It is suggested to combine Chaetoceros sp and Chlorella sp to reach continuous Phronima suppa production.

Potency possessed by Phronima suppa may be set as national leading product and substitution of Artemia salina to improve national product competitiveness of tiger prawn. Hence, national policy and private sector support are needed to improve this species.

\section{Credits}

Special thanks and respect to Director of Research and Community Service (ID: Dit. Litabmas) Directorate General of Higher Education of Ministry of Education and Culture of the Republic of Indonesia who supplies research fund as well as Bupati and local government of Pinrang Regency who supports us by setting Phronima suppa as one of local leading commodity.

\section{References}

1. Boyd CE, Clay JW (1998) Shrimp aquaculture and the environment. Sci Am 278: 58-65.

2. Burford MA, Williams KC (2001) The fate of nitrogenous waste from shrimp feeding. Aquaculture 198: 79-93.

3. Cheng S, Zhang WW, Zhang M, Sun L (2010) Evaluation of the vaccine potential of a cytotoxic protease and a protective immunogen from a pathogenic Vibrio harveyi strain. Vaccine 28: 1041-1047.

4. Cuéllar-Anjel J, White-Noble B, Schofield P, Chamorro R, Lightner DV (2012) Report of significant WSSV-resistance in the Pacific white shrimp, Litopenaeus vannamei, from a Panamanian breeding program. Aquaculture 368: 36-39.

5. Gauger E, Slomowitz R, Uhlinger K, Casey J, Gomez-Chiarri M (2006) Vibrio harveyi and other bacterial pathogens in cultured Summer flounder, Paralichthys dentatus. Aquaculture 260: 10-20.

6. Huang Y, Yin Z, Weng S, He J, Li S (2012) Selective breeding and preliminary commercial performance of Penaeus vannamei for resistance to white spot syndrome virus (WSSV). Aquaculture 364: 111-117.

7. Jackson C, Preston N, Thompson PJ, Burford M (2003) Nitrogen budget and effluent nitrogen components at an intensive shrimp farm. Aquaculture 218 : 397-411.

8. López JR, de la Roca E, Núñez S, de la Herran R, Navas JI, et al., (2009) Identification of Vibrio harveyi isolated from diseased cultured wedge sole Dicologoglossa cuneata. Dis Aquat Org 84: 209-217.

9. Luna-González A, Almaraz-Salas JC, Fierro-Coronado JA, Ma del Carmen Flores-Miranda, González-Ocampo HA, et al., (2012) The prebiotic inulin increases the phenoloxidase activity and reduces the prevalence of WSSV in whiteleg shrimp (Litopenaeus vannamei) cultured under laboratory conditions. Aquaculture 362: 28-32.

10. Soewardi K (2002) Pond water quality management. Paper presented in the seminar of water quality standard determination for pond waste. Ditjen of Cultura Fishery Perikanan, Ougust: 7 - 9.
11. Zhang ZF, Zhang WB, Liu LP (2012) Status and sustainability problems of white leg shrimp Litopenaeus vannamei culture in Zhanjiang. Guangdong Agric Sci 14: $158-160$

12. Fast AW, Menasveta $P(2000)$ Some recent issues and innovations in marine shrimp pond culture. Rev Fish Sci 8: 151-233.

13. Fattah $\mathrm{MH}$, dan Busaeri $\mathrm{R}$ (2002) Perubahan perilaku manajerial petan penerima bantuan saluran tambak (Studi kasus: Penanggulangan penyakit pada udang windu secara terpadu berbasis hamparan). Prosiding Konperensi Nasional III Pengelolaan Sumberdaya Pesisir dan Lautan Indonesia, Jakarta. 12 hal.

14. Tookwinas S (2003) Country Papers: Thailand: Aquaculture Management APO Seminar on Aquaculture Management held in the Republic of China, 3-8 December 2001. Asian Productivity Organization, Tokyo, and Taiwan Fisheries Research Institute, Keelung, pp. 239-254.

15. Tseng IT, Chen JC (2004) The immune response of white shrimp Litopenaeus vannamei and its susceptibility to Vibrio alginolyticus under nitrite stress. Fish Shellfish Immunol 17: 325-333.

16. Zhao GX, Liu LP, Li Y, Hu ZX (2012) Comparisons on water quality and production performance between integrated culture system of Litopenaeus vanammei and monoculture tank. Jiangsu Agric Sci 40: 202-206.

17. Fattah MH, Asbar Kasnir dan Saenong M (2008) Perencanaan Kawasan dan Bisnis Perikanan Terpadu di Sulawesi Selatan. Dinas Perikanan dan Kelautan Provinsi Sulawesi Selatan, Makassar.

18. Fattah MH, dan Saenong M (2008) Uji pendahuluan kultur Phronima suppa (Phronima sp). Laboratorium Lapang Akuakultur. Fakultas Perikanan dan IImu Kelautan, Universitas Muslim Indonesia (UMI), Makassar.

19. Tian XL, Li DS, Dong SL, Yan XZ, Qi ZX, et al., (2001) An experimental study on closed-polyculture of penaeid shrimp with tilapia and constricted tagelus. Aquaculture 202: 57-71.

20. Koniyo Y (2006) Biologi Dan Metode Kultur Plankton Sebagai Pakan Alami Larva Hewan Air.

21. Krichnavaruk S, Loataweesup W, Powtongsook S, Pavasant P (2005) Optimal Growth Conditions and The Cultivation of Chaetoceros calcitrans in Airlift Photobioreactor. Chemical Engineering Journal 105: 91-98.

22. Laing I (1979) Recommended Procedures for The Culture of Chatoceros calcitrans. Ministry of Agriculture, Fisheries, and Food Directorate of Fisheries Research. Lowestoft: 13-17.

23. Michiel HA, Michels MHA, Van der Goot AJ, Norsker NH, Wijfels RH (2010) Effects of shear stress on the microalgae Chaetoceros muelleri. Bioprocess Biosyst Eng 33: 921-927.

24. Mou SD, Li YS, Liu G, Wang Y (2000) A review of hatching, rearing and propagation technologies of sea cucumber (Apostichopus japonicus) in Shandong Province. Chinese Journal of Oceanology and Limnology 2: 63-65.

25. Sutomo (2005) Kultur Tiga Jenis Mikroalga (Tetraselmis Sp., Chlorella Sp. Dan Chaetoceros Gracilis) dan Pengaruh Kepadatan Awal Terhadap Pertumbuhan C. Gracilis di Laboratorium. Oseanologi dan Limnologi 37: 43-58.

26. Tendencia EA, Bosma RH, Primavera JH, Verreth JAJ (2012) Effect of differen mangrove-to-pond area ratios on influent water quality and WSSV occurrence in Penaeus monodon semi-intensive farms using the greenwater culture technique. Aquaculture 362: 72-79.

27. Fattah MH, Saenong M, Asbar dan Busaeri R (2012) Pengembangan metode produksi Phronima suppa (Phronima sp) secara buatan. Dit.Litabmas- DiktiKemendibud, Makassar. 
Citation: Fattah MH, Saenong M, Asbar, Busaeri SR (2014) Production of Endemic Microcrustacean Phronima Suppa (Phronima sp) to Subtitute Artemia salina in Tiger Prawn Cultivation. J Aquac Res Development 5: 257. doi:10.4172/2155-9546.1000257

28. Fattah MH, Saenong M, Haryati Asbar, Busaeri R (2013) Using of substrate for a micro-crustaceans endemic production Phronima suppa (Phronima sp) in controlled tank. Proceeding of International Seminar University of Hangtuah Surabaya, Surabaya, Indonesia.

29. Aquacop Bedier E, Soyez C (1988) Effects of dissolved oxygen concentration on survival and growth of Penaeus vannamei and Penaeus stylirostris. J World Aquacult Soc 19: 13A.

30. Avnimelech $Y$ (1999) Carbon/nitrogen ratio as a control element in aquaculture systems. Aquaculture 176: 227-235.

31. Cheng W, Liu CH, Kuo CM (2003) Effects of dissolved oxygen on hemolymph parameters of freshwater giant prawn, Macrobrachium rosenbergii (de Man). Aquaculture 220: 843-856.

32. Dong YW, Dong SL, Tian XL, Wang F, Zhang MZ (2006) Effects of die temperature fluctuations on growth, oxygen consumption and proximate body composition in the sea cucumber Apostichopus japonicus Selenka. Aquaculture 255: 514-521.

33. Environment Ministry (2004) Environment Ministry Decision No.51 in 2004 about sea water quality standard. Jakarta, Indonesia.

34. Gilbert F, Souchu P, Bianchi M, Bonin P (1997) Influence of shellfish farming activities on nitrification, nitrate reduction to ammonium and denitrification at the water sediment interface of the Thau lagoon, France. Marine Ecology Progress Series 151: 143-153.

35. Lal MM, Seeto J, Pickering TD, Hodge S (2012) Salinity and temperature requirements for larviculture of the Monkey River prawn Macrobrachium lar (Fabricius, 1798) (Decapoda: Caridea: Palaemonidae). Aquaculture 366: 1-8.

36. Liu F, Wang F, Dong SL, Ren YC, Tan FY (2009) Preliminary studies of wate quality in the feeding and unfed sea cucumber culture ponds. Journal of Ocean University of China 39: 369-374.

37. McGraw W, Teichert-Coddington DR, Rouse DB, Boyd CE (2001) Higher minimum dissolved oxygen concentrations increase penaeid shrimp yields in earthen ponds. Aquaculture 199: 311-321

38. Murphy J, Riley JP (1962) A modified single solution method for determination of phosphate in natural waters. Analytic Chimica Acta 27: 31-36.

39. Stirling HP, Okumus I (1995) Growth and production ofmussels (Mytilus edulis) suspendedatsalmon cages and shell fish farms in two Scottish sea lochs. Aquaculture 134: 193-210.
40. Taylor BE, Jamieson G, Carefoot TH (1992) Mussel culture in British Columbia: the influence of salmon farms on growth of Mytilus edulis. Aquaculture 108: 51-66.

41. Wyban J, Walsh WA, Godin DM (1995) Temperature effects on growth, feeding rate and feed conversion of the Pacific white shrimp (Penaeus vannamei). Aquaculture 138: 267-279.

42. Steel RGD, Torrie JH (1982) Principles and procedures of statistics: A biometrical approach. Mc Graw-Hill International Book Company, Tokyo, Japan.

43. Muangkeow B, Ikejima K, Powtongsook S, Yi Y (2007) Effects of white shrimp, Litopenaeus vannamei (Boone), and Nile tilapia, Oreochromis niloticus L., stocking density on growth, nutrient conversion rate and economic return in integrated closed recirculation system. Aquaculture 269: 363-376.

44. Asaduzzaman M, Rahman MM, Azim ME, Islam MA, Wahab MA, et al., (2010) Effects of $\mathrm{C} / \mathrm{N}$ ratio and substrate addition on natural food communities in freshwater prawn monoculture ponds. Aquaculture 306: 127-136.

45. Granberg ME, Selck H (2007) Effects of sediment organic matter quality on bioaccumulation, degradation, and distribution of pyrene in two macrofaunal species and their surrounding sediment. Marine Environmental Research 64: 313-335.

46. Gre'mare A, Medernach L, deBove'e F, Amoroux JM, Ve'tion G, et al., (2002) Relationships between sedimentary organics and benthic meiofauna on the continental shelf and the upper slope of the Gulf of Lions (NW Mediterranean). Marine Ecology Progress Series 234: 85-94.

47. Renaud SM, Thinh LV, David DL (1999) The Gross Chemical Composition and Fatty Acid Composition of 18 Species of Tropical Australian Microalgae for Possible Use in Mariculture. Aquaculture 170: 147-159.

48. Krebs CJ (2001) Population Growth. In Ecologi: The experimental analysis of distribution and abundance, Benjamin Cummings, California, USA.

49. Odum EP (1971) Fundamental of ecology. WB Saunders Company, Philadelphia, London, UK.

50. Yi Y (1998) A bioenergetics growth model for Nile tilapia (Oreochromis niloticus) based on limiting nutrients and fish standing crop in fertilized ponds. Aquac Eng 18: $157-173$ 